А. И. Юсевич, В. В. Цалко, Е. М. Осипенок, Д. В. Куземкин

Белорусский государственный технологический университет

\title{
СИНТЕЗ И СВОЙСТВА 2-АЛКИЛ-1-(2-АМИНОЭТИЛ)-2-ИМИДАЗОЛИНОВ
}

Изучены закономерности реакции ацилирования диэтилентриамина (ДЭТА) насыщенными монокарбоновыми кислотами состава $\mathrm{C}_{16}-\mathrm{C}_{18}$, в том числе влияние избытка ДЭТА на относительный выход его моноацильного производного (аминоамида) и диацильного производного (диамида). Установлено, что даже многократный избыток ДЭТА не подавляет образование диамида, что негативно сказывается на последующей стадии циклизации аминоамида, приводя к снижению выхода и качества целевого 2-алкил-1-(2-аминоэтил)-2-имидазолина. Предложен механизм протекания реакций ацилирования и циклизации при взаимодействии диэтилентриамина с высшими жирными кислотами, объясняющий наблюдаемые закономерности. На основе предложенного механизма разработана и реализована методика синтеза 2-алкил-1-(2-аминоэтил)-2-имидазолинов из жирных кислот и диэтилентриамина с высоким выходом в однореакторной системе без дополнительных стадий выделения и очистки. Синтезированы 1-(2-аминоэтил)-2-пентадецил-2-имидазолин и 1-(2-аминоэтил)-2-гептадецил-2-имидазолин из технической смеси пальмитиновой и стеариновой кислот без разделения. Построены изотермы поверхностного натяжения водных растворов уксуснокислых солей полученного смесевого ПАВ на границе с воздухом в диапазоне температур $20-60^{\circ} \mathrm{C}$, определены параметры мицеллообразования и адсорбции. Изучено противокоррозионное действие синтезированных 2-алкил-1-(2-аминоэтил)-2-имидазолинов по отношению к углеродистой стали в водно-солевом растворе.

Ключевые слова: стеарин, ДЭТА, алкилимидазолин, катионное ПАВ, водный раствор, поверхностное натяжение, критическая концентрация мицеллообразования, работа адсорбции, ингибитор коррозии.

Для цитирования: Юсевич А. И., Цалко В. В., Осипенок Е. М., Куземкин Д. В. Синтез и свойства 2-алкил-1-(2-аминоэтил)-2-имидазолинов // Труды БГТУ. Сер. 2, Химические технологии, биотехнологии, геоэкология. 2021. № 2 (247). С. 144-152.

\section{A. I. Usevich, V. V. Tsalko, K. M. Asipionak, D. V. Kuzemkin \\ Belarusian State Technological University}

\section{SYNTHESIS AND PROPERTIES OF 2-ALKYL-1-(2-AMINOETHYL)-2-IMIDAZOLINES}

The features of diethylenetriamine (DETA) acylation reaction with $\mathrm{C}_{16}-\mathrm{C}_{18}$ saturated monocarboxylic acids have been studied, including the effect of an excess of DETA on the relative yield of its monoacyl derivative (aminoamide) and diacyl derivative (diamide). It was found that even a multiple excess of DETA does not suppress the formation of diamide, which negatively affects the subsequent stage of the aminoamide cyclization, leading to a decrease in the yield and quality of the target 2-alkyl-1(2-aminoethyl) -2-imidazoline. The mechanism of the acylation and cyclization reactions during the interaction of diethylenetriamine with higher fatty acids is proposed, which explains the observed regularities. Based on the proposed mechanism, a procedure for the high yield synthesis of 2-alkyl-1-(2-aminoethyl)-2-imidazolines from fatty acids and diethylenetriamine in a one-pot system without the need for additional isolation and purification was developed and implemented. 1-(2-Aminoethyl)-2-pentadecyl-2imidazoline and 1-(2-aminoethyl)-2-heptadecyl-2-imidazoline were synthesized from a technical mixture of palmitic and stearic acids without separation. Aqueous solutions of acetic acid salts of the obtained mixed surfactant were prepared and the isotherms of their surface tension at the interface with air were measured at temperatures of $20-60^{\circ} \mathrm{C}$. The anticorrosive effect of the synthesized 2-alkyl-1-(2-aminoethyl)-2-imidazolines in relation to carbon steel in a water-salt solution has been studied.

Key words: stearin, DETA, alkylimidazoline, cationic surfactant, aqueous solution, surface tension, critical micelle concentration, adsorption work, corrosion inhibitor.

For citation: Usevich A. I., Tsalko V. V., Asipionak K. M., Kuzemkin D. V. Synthesis and properties of 2-alkyl-1-(2-aminoethyl)-2-imidazolines. Proceedings of BSTU, issue 2, Chemical Engineering, Biotechnologies, Geoecology, 2021, no. 2 (247), pp. 144-152 (In Russian).

Введение. Производные 2-имидазолина (4,5-дигидро- $1 H$-имидазола) составляют обширную группу гетероциклических органических соединений, включающую биологически активные, химически активные и поверхностно-активные вещества, которые находят применение 
в различных сферах человеческой деятельности. Они используются как лекарственные средства [1], хиральные органокатализаторы или лиганды металлокомплексных катализаторов органических реакций [2], эмульгаторы, детергенты, флокулянты, смягчители и антистатики тканей [3], ингибиторы коррозии металлов $[4,5]$. Поэтому наблюдаемый последние два десятилетия повышенный интерес к разработке и совершенствованию методов синтеза имидазолинов и изучению их свойств является вполне закономерным.

2-Алкил-2-имидазолины с 9-21 атомом углерода в боковой цепи являются поверхностно-активными веществами. Их коллоидно-химические свойства в значительной степени варьируются в зависимости от длины алкильного радикала и наличия других заместителей в кольце [6]. Это обусловливает широкое применение имидазолиновых ПАВ в составе моющих средств, косметических препаратов, замасливателей текстильных нитей, а также для защиты нефтепромыслового и нефтезаводского оборудования от коррозии.

Одним из наиболее распространенных методов синтеза поверхностно-активных алкилимидазолинов является реакция этилендиамина или его полиаминоэтиленовых гомологов с жирными кислотами или их сложными эфирами. Синтез идет через стадии ацилирования полиамина (I) и циклизации моноацильного производного (II), как показано на схеме 1.

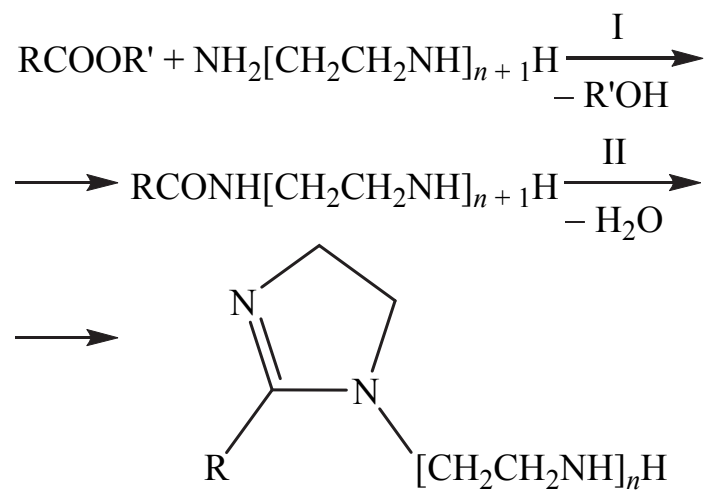

Схема 1. Синтез 2-алкил-2-имидазолинов: $\mathrm{R}$ - алкил $\mathrm{C}_{9}-\mathrm{C}_{21} ; \mathrm{R}^{\prime}-\mathrm{H}, \mathrm{CH}_{3}, \mathrm{C}_{2} \mathrm{H}_{5}$, $\mathrm{CH}_{2} \mathrm{CH}(\mathrm{OOCR}) \mathrm{CH}_{2} \mathrm{OOCR} ; n \geq 0$

Наряду с аминоамидом может образовываться диацильное производное полиаминного реагента, так называемый диамид (схема 2).

Диамид мало растворим в воде и органических растворителях, имеет низкую поверхностную активность и ухудшает свойства товарного имидазолина, обусловливая необходимость очистки последнего методами ректификации или экстракции. Дополнительные стадии очистки удорожают продукт.

$$
\begin{aligned}
& \mathrm{RCONH}\left[\mathrm{CH}_{2} \mathrm{CH}_{2} \mathrm{NH}\right]_{n+1} \mathrm{H}+\mathrm{RCOOR}^{\prime} \\
& \mathrm{RCONH}\left[\mathrm{CH}_{2} \mathrm{CH}_{2} \mathrm{NH}\right]_{n+1} \mathrm{COR} \text { (диамид) } \\
& \text { IV } \mathrm{RCONH}_{2}-\mathrm{CH}_{2} \mathrm{CH}_{2}\left[\mathrm{CH}_{2} \mathrm{CH}_{n+1} \mathrm{H} \mathrm{NH}_{n+1} \mathrm{H}\right.
\end{aligned}
$$

Схема 2. Пути образования диамида

Соотношение выходов имидазолина и диамида существенно зависит от электрофильности карбонильного углерода ацилирующего агента и, следовательно, от длины углеводородного радикала карбоновой кислоты. Поэтому для разных жирных кислот оптимальные условия синтеза алкилимидазолинов различаются. Вместе с тем на практике для снижения себестоимости получаемых ПАВ часто используют в качестве сырья не индивидуальные карбоновые кислоты, а их технические смеси, например стеарин. Это может приводить к снижению выхода имидазолинов и ухудшению их свойств из-за неоптимальных условий синтеза.

Исходя из вышесказанного была поставлена цель настоящей работы, которая заключалась в изучении особенностей и оптимизации условий синтеза 2-алкил-2-имидазолинов из смеси карбоновых кислот, а также оценка поверхностноактивных и противокоррозионных свойств полученного смесевого ПАВ.

Основная часть. Для синтеза 2-алкил-1-(2аминоэтил)-2-имидазолинов использовали диэтилентриамин ( $\geq 98 \%)$ от Acros Organics и техническую стеариновую кислоту (табл. 1) без дополнительной очистки. Показатели качества стеариновой кислоты определяли в соответствии с ГОСТ 6484-96. Так как техническая стеариновая кислота по сути оказалась смесью стеариновой и пальмитиновой кислот в соизмеримых количествах, в дальнейшем для наименования этого реагента использовали термин «стеарин».

При поиске оптимальных условий синтеза за основу была взята распространенная методика получения алкилимидазолинов $[5,6]$, предусматривающая единовременное смешение карбоновой кислоты с небольшим избытком полиамина при комнатной температуре и последующий ступенчатый нагрев до $250-270^{\circ} \mathrm{C}$, в течение которого протекают реакции ацилирования амина и циклизации амида. Для облегчения удаления реакционной воды на стадии ацилирования могут использоваться азеотропные агенты или продувка инертным газом, а на стадии 
циклизации - вакуум. Мы воспроизвели указанные условия, однако не смогли достичь высокого выхода алкилимидазолинов, поэтому в дальнейшем усовершенствовали методику их получения. Ниже приведено описание проведенных нами опытов в хронологической последовательности, приведшей к оптимальным, на наш взгляд, условиям синтеза.

Таблица 1

Характеристика технической стеариновой кислоты (стеарина)

\begin{tabular}{|l|c|}
\hline \multicolumn{1}{|c|}{ Показатель } & Значение \\
\hline Цвет, ед. Хазена & 100 \\
\hline Йодное число, г $\mathrm{I}_{2} / 100$ г & 3,0 \\
\hline Кислотное число, мг КОН/Г & 204,7 \\
\hline Число омыления, мг КОН/г & 205,8 \\
\hline Температура застывания, ${ }^{\circ} \mathrm{C}$ & 55,1 \\
\hline Массовая доля влаги, \% $^{2}$ & 0,16 \\
\hline Содержание жирных кислот*, мас. \%: ${ }^{2}$ & \\
$\mathrm{C}_{12}+\mathrm{C}_{14}$ & 0,6 \\
$\mathrm{C}_{16}$ & 51,9 \\
$\mathrm{C}_{18}$ & 47,1 \\
$\mathrm{C}_{20+}$ & 0,4 \\
\hline
\end{tabular}

*Метод газожидкостной хроматографии: HP 4890D, пламенно-ионизационный детектор, капиллярная колонка HP-Innowax (30 м × 0,32 мм $\times 0,5$ мкм), гелий.

Синтез 1. В двугорлую колбу, снабженную термометром, насадкой Вюрца с холодильником Либиха, трубкой для подвода инертного газа и магнитной мешалкой, загружали 136 г ( 0,5 моль) стеарина и 103 г (1 моль) диэтилентриамина. Смесь нагревали до $70^{\circ} \mathrm{C}$, дожидались расплавления стеарина, включали перемешивание и подачу аргона и продолжали нагрев до $180^{\circ} \mathrm{C}$.

При температурах выше $130^{\circ} \mathrm{C}$ наблюдали конденсацию паров воды в холодильнике, конденсат собирали в приемнике. Реакционную смесь выдерживали при $180^{\circ} \mathrm{C}$ в течение 1 ч до прекращения выделения воды. Затем продолжали подъем температуры вплоть до $270^{\circ} \mathrm{C}$

Выше $210^{\circ} \mathrm{C}$ отгонялся избыток диэтилентриамина, после $250^{\circ} \mathrm{C}$ начала отгоняться реакционная вода. При $270^{\circ} \mathrm{C}$ реакционную смесь выдерживали 1 ч, затем не снижая температуры вакуумировали при 200 мм рт. ст. еще 1 ч для завершения циклизации и удаления следов воды.

На этом синтез прекращали, полученный продукт анализировали методами инфракрасной спектроскопии и газожидкостной хроматографии.
Инфракрасные спектры записывали на ИКФурье спектрометре ФСМ 1202 (ООО «Инфраспек»), нанося пробы на кристалл бромида калия. Хроматографию проводили на приборе «Хроматэк-Кристалл 5000.2» (ЗАО СКБ «Хроматэк») с пламенно-ионизационным детектором и капиллярной колонкой Restek MXT-1 (полидиметилсилоксан, 30 м $\times 0,53$ мм $\times 0,25$ мкм), газноситель - водород. Температуру колонки поднимали от 30 до $360^{\circ} \mathrm{C}$ со скоростью $10^{\circ}$ ммин при расходе газа-носителя 10 мл/мин и сбросе 9:1. Массовое содержание компонентов в реакционной смеси оценивали по соотношению площадей хроматографических пиков.

В ИК-спектре продукта синтеза 1 (рис. $1, a$ ) помимо полосы валентных колебаний $\mathrm{C}=\mathrm{N}$ при $1608 \mathrm{~cm}^{-1}$ (отнесенной нами к имидазолиновому циклу) были обнаружены интенсивные полосы поглощения амидной группы: $1668 \mathrm{~cm}^{-1}$ (валентные колебания $\mathrm{C}=\mathrm{O}$ ) и $1556 \mathrm{~cm}^{-1}$ (деформационные колебания $\mathrm{N}-\mathrm{H}$ ). Они были обусловлены значительным присутствием диамидов в продукте. На это указывала также большая интенсивность полосы при $721 \mathrm{~cm}^{-1}$, относящейся к деформационным колебаниям C-H в длинных алифатических цепях, доля которых в структуре диамида в 2 раза больше, чем в моноацильном производном диэтилентриамина.

На хроматограмме (рис. 1, г) были идентифицированы пики 1-(2-аминоэтил)-2-пентадецил-2-имидазолина (пик 1) и 1-(2-аминоэтил)-2гептадецил-2-имидазолина (пик 2). Соотношение площадей этих пиков составило 2,74:1, что соответствовало $\sim 2,9$-кратному мольному избытку алкилимидазолина, полученного из пальмитиновой кислоты.

Для сравнения, в исходном стеарине мольное соотношение кислот $\mathrm{C}_{16}$ и $\mathrm{C}_{18}$ было равным 1,2:1 (1,1:1 по массе, согласно табл. 1).

Очевидно, чем длиннее углеводородный радикал в моноацильном производном диэтилентриамина, тем менее оно склонно к циклизации (реакция II, схема 1) и в большей степени вступает в реакции, приводящие к диамиду (схема 2).

Пики 3, 4 и 5 на хроматограммах были нами отнесены к диамидам - продуктам ацилирования диэтилентриамина двумя молекулами пальмитиновой кислоты (пик 3), молекулами пальмитиновой и стеариновой кислот (пик 4) и двумя молекулами стеариновой кислоты (пик 5). Соотношение площадей пиков алкилимидазолинов и диамидов на хроматограмме рис. 1,2 оказалось близким к единице $(0,98: 1)$. Суммарное содержание алкилимидазолинов в продукте синтеза 1 , вычисленное как отношение площадей пиков 1 и 2 к суммарной площади хроматограммы, составило $43,9 \%$. 

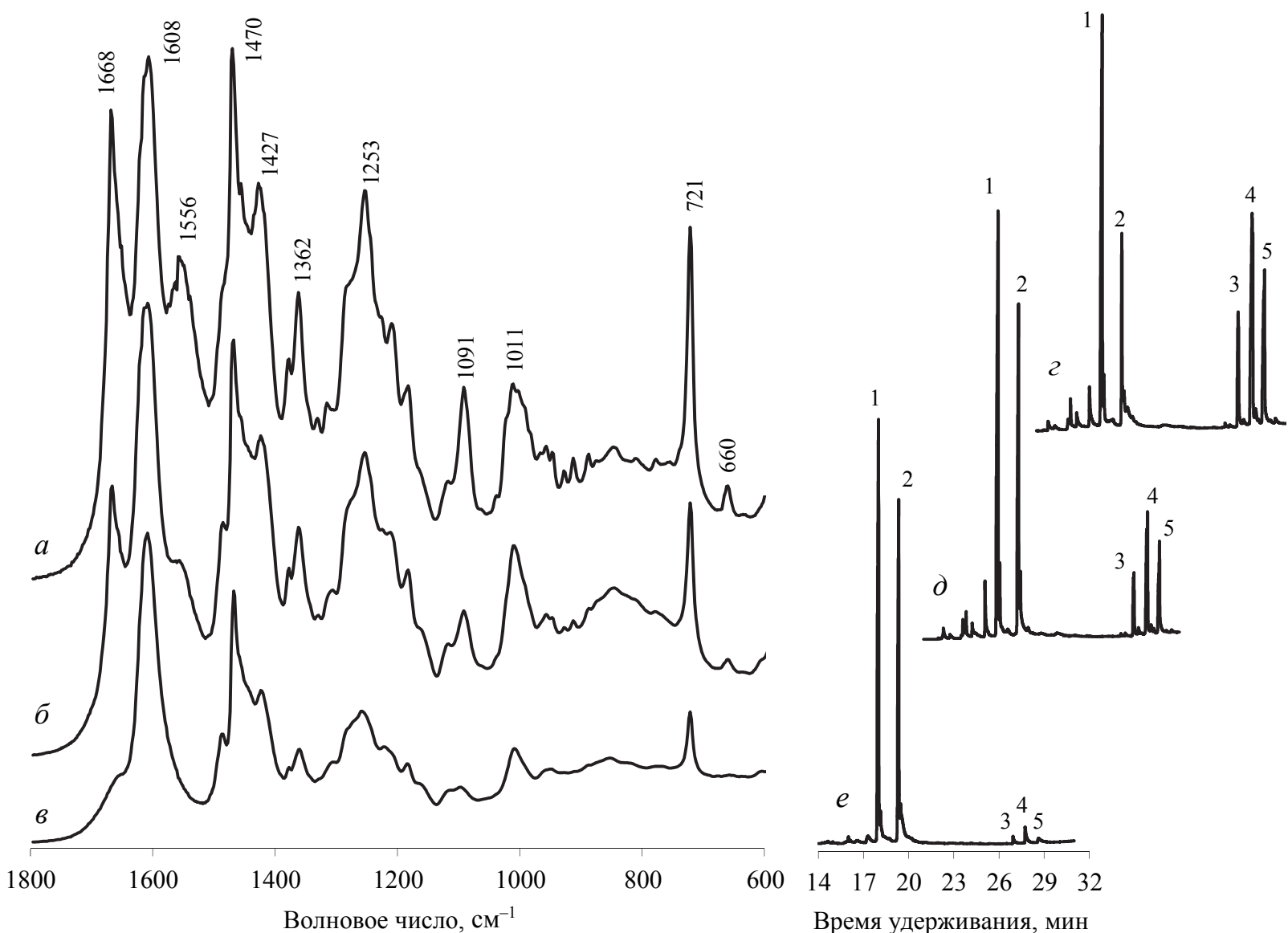

Рис. 1. Фрагменты инфракрасных спектров $(a-b)$ и хроматограмм $(2-e)$ продуктов синтеза: $a, z$-синтез $1 ; \sigma, \partial$-синтез $2 ; в, e$ - синтез 3 (расшифровка хроматографических пиков приведена по тексту)

Синтез 2. Для смещения равновесия реакции IV (схема 2) в сторону моноацильных производных диэтилентриамина и уменьшения выхода диамидов было решено увеличить избыток диэтилентриамина в реакционной смеси до пятикратного. В реакционную колбу вносили 54 г ( 0,2 моль) стеарина, 103 г (1 моль) диэтилентриамина и повторяли процедуру синтеза 1. В ИК-спектре полученного продукта (рис. 1, б) было отмечено уменьшение интенсивности амидных полос по сравнению с имидазолиновым пиком, однако они не исчезли вовсе. Соотношение пентадецил- и гептадецилимидазолина по хроматограмме (рис. 1, 2 ) составило 1,36:1, т. е. уменьшилось в 2 раза по сравнению с синтезом 1. Произошло это, очевидно, за счет увеличения образования более тяжелого гомолога. При этом соотношение площадей пиков алкилимидазолинов и диамидов увеличилось практически в 3 раза, до 2,9:1. Содержание алкилимидазолинов в продукте синтеза 2 составило 66,1 хромат. \%.

Тем не менее даже пятикратный избыток диэтилентриамина не подавил образование диамидов, присутствие которых в смеси было попрежнему значительно. Объяснить это можно исходя из механизма химических превращений, представленного на схеме 3.
При одновременной загрузке реагентов карбоновая кислота образует отдельную фазу, в которой существует в виде димеров (А). По мере нагрева реакционной смеси димеры взаимодействуют с диэтилентриамином (реакция V) с образованием тройных молекулярных комплексов кислота - амин - кислота (Б), независимо от соотношения реагентов в смеси. При относительно невысоких температурах (до $\sim 130^{\circ} \mathrm{C}$ ) молекулярные донорно-акцепторные комплексы преобразуются в более стабильные структуры (B) с полным переходом протона (реакция VI), способные к ионному обмену. Далее под действием избытка диэтилентриамина эти тройные комплексы частично превращаются в бинарные (Г) путем обмена протоном (реакция VII).

При подъеме температуры выше $130^{\circ} \mathrm{C}$ равновесие реакций VI и VIII смещается в сторону молекулярных комплексов с неразделенными зарядами (Б) и (Д), внутри которых происходит амидирование. При этом наиболее важным для получения целевого продукта является реакция IX превращения бинарного комплекса (Д) непосредственно в аминоамид, который при дальнейшем нагреве выше $250^{\circ} \mathrm{C}$ даст требуемый 2-алкил-1-(2-аминоэтил)-2-имидазолин по реакции X. 


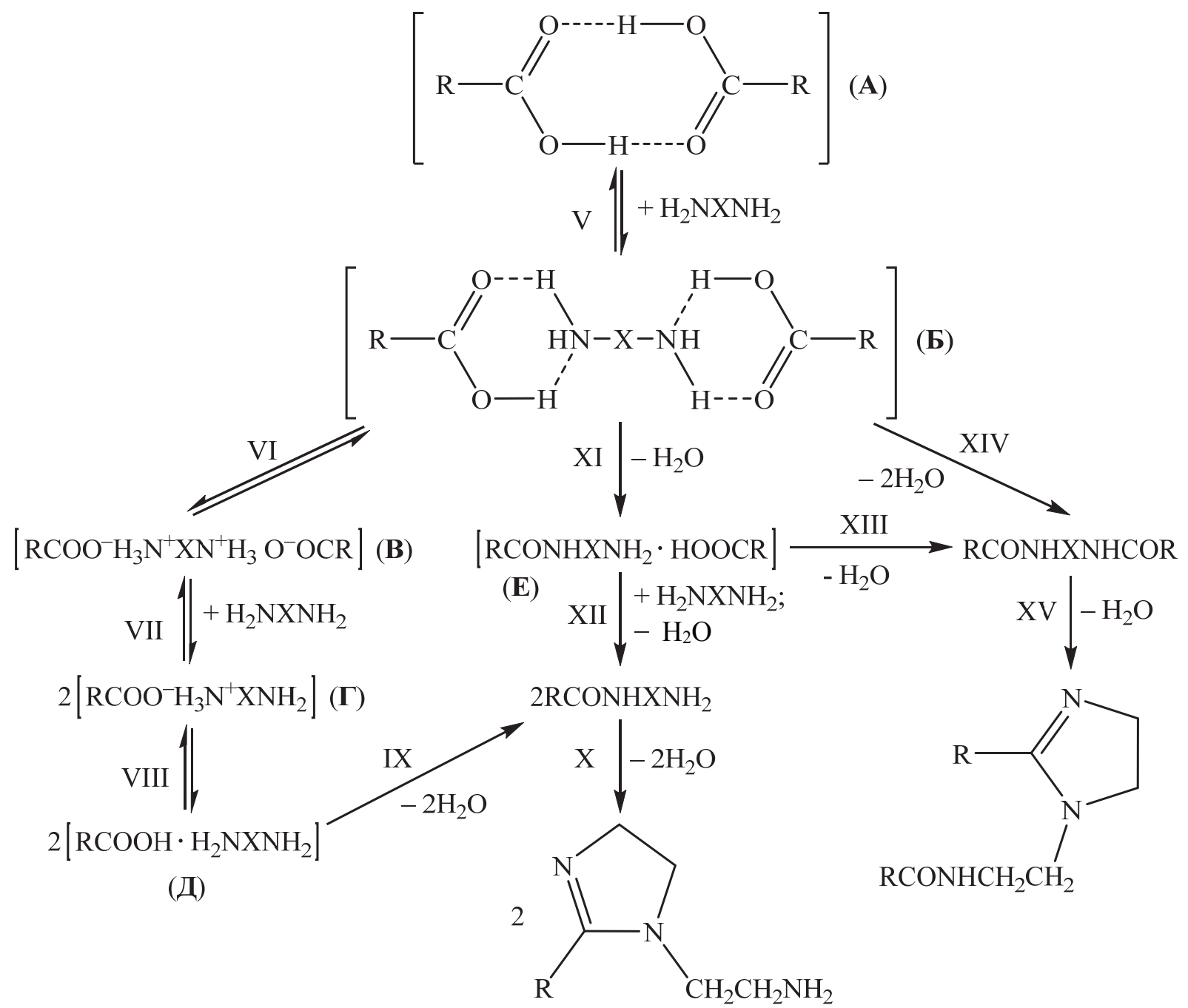

Схема 3. Механизм образования 2-алкил-1-(2-аминоэтил)-2-имидазолинов и побочных продуктов: $\mathrm{X}=\left(\mathrm{CH}_{2}\right)_{2} \mathrm{NH}\left(\mathrm{CH}_{2}\right)_{2}$

Тройной комплекс (Б) также может превращаться в аминоамид в результате протекания последовательных реакций амидирования XI и XII, однако с ними конкурируют побочные реакции XIII и XIV, приводящие к диамиду. Учитывая, что образование комплекса (Б) первично по отношению к комплексу (Д) и внутрикомплексная реакция XIII протекает быстрее, чем межмолекулярное взаимодействие XII, побочное образование диамида неизбежно при любом разумном с практической точки зрения избытке диэтилентриамина.

Следует также отметить, что наряду с циклизацией аминоамидов возможна циклизация диамидов (реакция XV), приводящая к 2-алкил-1-(2ациламиноэтил)-2-имидазолинам. Так, на хроматограммах продуктов синтезов 1 и 2 (рис. $1,2, \partial$ ) они проявлялись в виде расщепления пиков 3,4 , 5 из-за близкой к диамидам молекулярной массы.

Таким образом, для снижения выхода диамидов при синтезе алкилимидазолинов следует избегать образования тримолекулярных комплексов типа (Б), что было достигнуто нами за счет изменения порядка и температуры смешения реагентов в синтезе 3 .
Синтез 3. В трехгорлую колбу с термометром, насадкой Вюрца с холодильником Либиха, подводом инертного газа и магнитной мешалкой загружали 103 г (1 моль) диэтилентриамина, нагревали до $180^{\circ} \mathrm{C}$ и в течение 1 ч вносили порциями 136 г ( 0,5 моль) стеарина при интенсивном перемешивании. Практически сразу с началом подачи второго реагента наблюдалась отгонка воды. Большой локальный избыток амина при постепенном добавлении кислоты препятствовал образованию ее димеров и вместе с высокой начальной температурой реакционной смеси способствовал протеканию бимолекулярной реакции ацилирования I (схема 1) без промежуточного образования солей аммония. В конце добавления кислоты взятый в двухкратном избытке амин препятствовал образованию диамидов по реакции IV (схема 2). После введения всего стеарина реакционную смесь нагревали до $270^{\circ} \mathrm{C}$, проходя все те же стадии, что и в синтезе 1.

В результате был получен продукт, в ИКспектре которого (рис. 1, в) практически отсутствовали амидные полосы при наличии интенсивного 
имидазолинового пика. Площадь пиков алкилимидазолинов на хроматограмме (рис. $1, e$ ) в 25 раз превышала площадь пиков диамидов и составляла 95,9\% от суммарной площади хроматограммы. При этом отношение 1-(2-аминоэтил)-2-пентадецил-2-имидазолина к 1-(2-аминоэтил)-2-гептадецил-2-имидазолину было равным 1,25:1

Таким образом, продукт синтеза 3 представлял собой концентрат алкилимидазолинов с минимальной примесью диамидов, поэтому далее исследовали его поверхностно-активные и противокоррозионные свойства.

Изучение поверхностной активности. Измеряли поверхностное натяжение серии водных растворов уксуснокислых солей 2-алкил-1-(2аминоэтил)-2-имидазолинов на границе с воздухом сталагмометрическим методом [7]. Строили изотермы поверхностного натяжения при температурах 20,40 и $60^{\circ} \mathrm{C}$ (рис. 2).

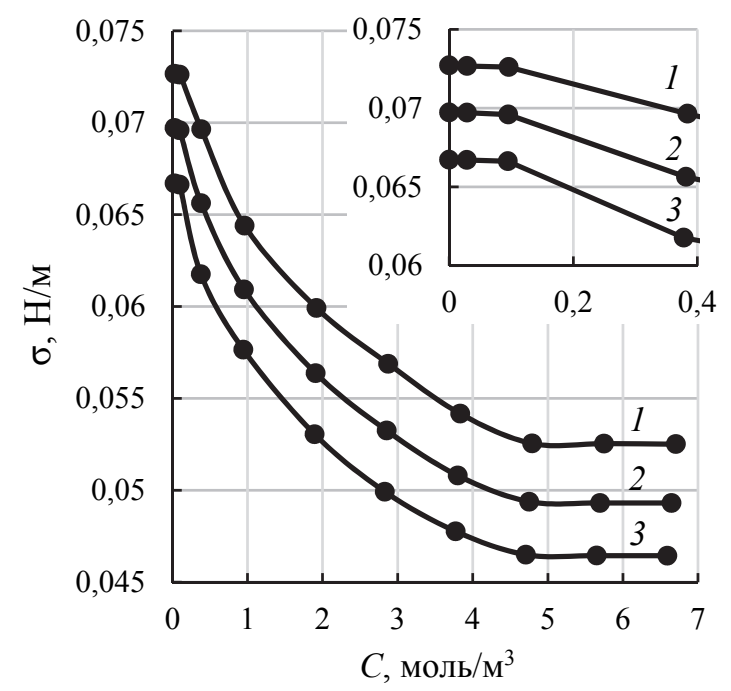

Рис. 2. Изотермы поверхностного натяжения водных растворов смеси уксуснокислых солей

1-(2-аминоэтил)-2-пентадецил-2-имидазолина и 1-(2-аминоэтил)-2-гептадецил-2-имидазолина (1,25:1): $1-20^{\circ} \mathrm{C} ; 2-40^{\circ} \mathrm{C} ; 3-60^{\circ} \mathrm{C}$

Особенностью полученных изотерм было то, что на начальных их участках $\left(<0,1\right.$ моль/м $\left.{ }^{3}\right)$ поверхностное натяжение снижалось слабо (вставка на рис. 2), что характерно для хорошо растворимых ПАВ, адсорбция которых на границе раздела фаз мала при низких концентрациях в растворе.
В области более высоких концентраций поверхностное натяжение растворов резко уменьшалось и изотермы имели вид, свойственный индивидуальным коллоидным ПАВ, с выходом на плато в результате образования мицелл в объеме фазы. Четко выраженных перегибов, присущих изотермам смесевых ПАВ, не наблюдалось, по-видимому, из-за близких коллоидно-химических свойств пентадецил- и гептадецилимидазолинов. Это позволило определить параметры мицеллообразования по общепринятым методикам [7].

В табл. 2 приведены критические концентрации мицеллообразования (ККМ), выраженные в мольных долях $\left(N_{\mathrm{M}}\right)$, соответствующие им молярные концентрации $\left(C_{\mathrm{M}}\right)$ и поверхностное натяжение $\left(\sigma_{\mathrm{M}}\right)$ растворов. По значениям $N_{\mathrm{M}}$ было рассчитано изменение свободной энергии Гиббса $\left(\Delta G_{\mathrm{M}}\right)$ при образовании мицелл:

$$
\Delta G_{\mathrm{M}}=R T \ln \left(N_{\mathrm{M}}\right) .
$$

Средние значения энтальпии $\left(\Delta H_{\mathrm{M}}\right)$ и энтропии $\left(\Delta S_{\mathrm{M}}\right)$ мицеллообразования в исследованном диапазоне температур определили путем аппроксимации температурной зависимости $\Delta G_{\mathrm{M}}$ известным термодинамическим уравнением:

$$
\Delta G_{\mathrm{M}}=\Delta H_{\mathrm{M}}-T \Delta S_{\mathrm{M}} \text {. }
$$

Из табл. 2 видно, что процесс мицеллообразования протекает с небольшим выделением тепла, однако основной вклад в уменьшение свободной энергии системы вносит положительный энтропийный фактор, указывающий на определяющую роль гидрофобных взаимодействий молекул ПАВ

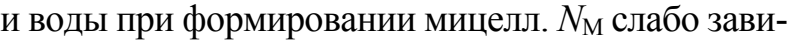
сит от температуры, немного увеличиваясь с ее ростом. Наблюдаемое при этом незначительное снижение $C_{\mathrm{M}}$ объясняется уменьшением плотности водных растворов с увеличением температуры.

В работах [8, 9] были определены критические параметры мицеллообразования для водных растворов солей 2-алкил-2-имидазолинов с 15-17 атомами углерода в алкильной цепи, не замещенных в положении 1 кольца: $C_{\mathrm{M}}=0,38$ 1,46 моль $/ \mathrm{M}^{3} ; \sigma_{\mathrm{M}}=33,3-40,8 \mathrm{MH} / \mathrm{M}$. В нашем случае (табл. 2) ККМ и минимальное поверхностное натяжение оказались значительно больше, что может быть обусловлено лучшей растворимостью 2-алкил-1-(2-аминоэтил)-2-имидазолинов в воде за счет сольватации дополнительной аминогруппы.

Таблица 2

Параметры мицеллообразования смеси уксуснокислых солей 1-(2-аминоэтил)-2-пентадецил-2-имидазолина

\begin{tabular}{|c|c|c|c|c|c|c|}
\hline$t,{ }^{\circ} \mathrm{C}$ & $N_{\mathrm{M}} \cdot 10^{5}$ & $C_{\mathrm{M}}$, моль $/ \mathrm{M}^{3}$ & $\sigma_{\mathrm{M}}, \mathrm{MH} / \mathrm{M}$ & $\Delta G_{\mathrm{M}}$, кДж/моль & $\Delta H_{\mathrm{M}}$, Дж/моль & $\Delta S_{\mathrm{M}}$, Дж/моль $\cdot \mathrm{K}$ \\
\hline 20 & 8,24 & 4,53 & 52,5 & $-22,9$ & \multirow{3}{*}{$-156,2$} & \multirow{3}{*}{77,6} \\
\hline 40 & 8,29 & 4,52 & 49,3 & $-24,5$ & & \\
\hline 60 & 8,31 & 4,49 & 46,5 & $-26,0$ & & \\
\hline
\end{tabular}
и 1-(2-аминоэтил)-2-гептадецил-2-имидазолина $(1,25: 1)$ в водном растворе 
Таблица 3

Параметры адсорбции смеси уксуснокислых солей 1-(2-аминоэтил)-2-пентадецил-2-имидазолина и 1-(2-аминоэтил)-2-гептадецил-2-имидазолина $(1,25: 1)$ в системе вода - воздух

\begin{tabular}{|c|c|c|c|c|c|c|c|}
\hline$t,{ }^{\circ} \mathrm{C}$ & $\Gamma_{m} \cdot 10^{6}$, моль $/ \mathrm{M}^{2}$ & $\begin{array}{c}\alpha, \\
\text { моль } / \mathrm{M}^{3}\end{array}$ & $K$ & $S_{m} \cdot 10^{20}, \mathrm{M}^{2}$ & $\begin{array}{c}W, \\
\text { кДж/моль }\end{array}$ & $\begin{array}{c}\Delta H, \\
\text { Дж/моль }\end{array}$ & $\begin{array}{c}\Delta S, \\
\text { Дж/моль } \cdot \mathrm{K}\end{array}$ \\
\cline { 1 - 5 } 20 & 9,16 & 2,21 & 4142,9 & 18,1 & 20,3 & & \\
\cline { 1 - 5 } & 8,49 & 2,05 & 4136,1 & 19,6 & 21,7 & $-305,9$ & 68,2 \\
\hline 60 & 7,78 & 1,91 & 4082,0 & 21,3 & 23,0 & & \\
\hline
\end{tabular}

Количественные характеристики адсорбции ПАВ на границе вода - воздух (табл. 3) были определены так же, как и в работе [9], путем построения изотерм адсорбции Гиббса (рис. 3 ) и аппроксимации их начальных участков уравнением Лэнгмюра. Были найдены константы уравнения Лэнгмюра: предельная адсорбция $\Gamma_{m}$ и параметр $\alpha$, по которым были вычислены посадочные площадки молекул $\left(S_{m}\right)$, константы адсорбционного равновесия $(K)$ и работа адсорбции $(W)$. Аппроксимация температурной зависимости работы адсорбции линейной функцией позволила определить энтальпию $(\Delta H)$ и энтропию $(\Delta S)$ адсорбции.

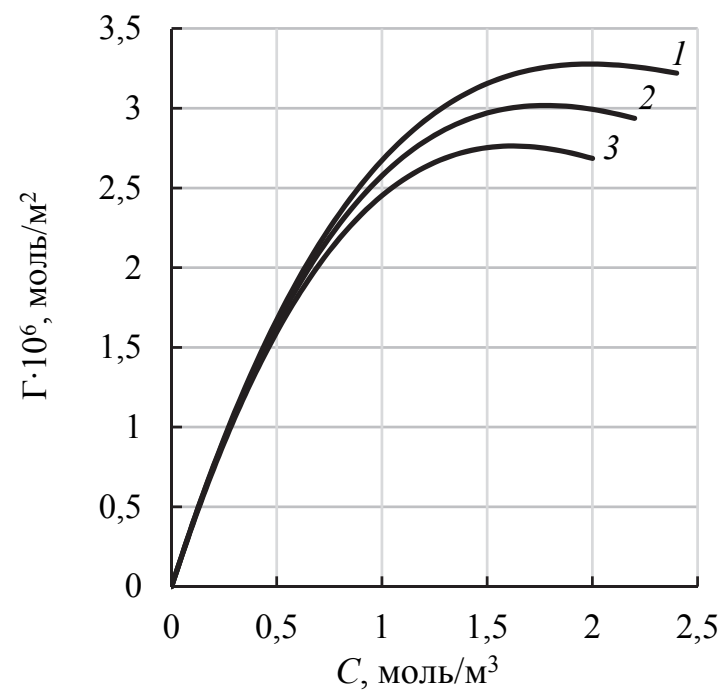

Рис. 3. Изотермы адсорбции Гиббса смеси уксуснокислых солей

1-(2-аминоэтил)-2-пентадецил-2-имидазолина и 1-(2-аминоэтил)-2-гептадецил-2-имидазолина $(1,25: 1)$ на границе вода - воздух: $1-20^{\circ} \mathrm{C} ; 2-40^{\circ} \mathrm{C} ; 3-60^{\circ} \mathrm{C}$

Согласно данным табл. 3, несмотря на экзотермичность процесса адсорбции вклад энтальпийной составляющей в величину работы адсорбции невелик и определяющее влияние на поверхностную активность алкилимидазолинов оказывает энтропийный фактор, обусловленный гидрофобными взаимодействиями алифатических цепей ПАВ и молекул воды.
При вытеснении алкильной группы ПАВ из объема фазы в поверхностный слой увеличивается ее число степеней свободы, растет энтропия и, соответственно, уменьшается свободная энергия молекулы. Уменьшение свободной энергии (работа адсорбции) будет тем больше, чем больше метиленовых групп гидрофобного «хвоста» выйдет на поверхность. Этому процессу препятствует сольватация гидрофильной части ПАВ, втягивающая алкильные группы обратно в объем фазы. Установленные в рамках настоящего исследования значения работы адсорбции и константы адсорбционного равновесия 2-алкил-1-(2-аминоэтил)-2-имидазолинов (табл. 3) оказались ниже значений, полученных в работе [9] для аналогичных по длине алкильных групп 2-алкил-2-имидазолинов. Причиной, по-видимому, является более сильная гидратация имидазолинового кольца, имеющего дополнительную аминоэтильную группу, по сравнению с незамещенным имидазолином. Возможен также стерический эффект бокового заместителя, увеличивающий площадь посадочной площадки молекулы и препятствующий плотному заполнению адсорбционного слоя.

Изучение противокоррозионных свойств. Испытание смеси 2-алкил-1-(2-аминоэтил)-2-имидазолинов в качестве ингибитора коррозии стали Ст3 проводили гравиметрическим методом в статических условиях по ГОСТ 9.502-82. В качестве коррозионной среды использовали модельный водно-солевой раствор по ГОСТ 9.506-87 следующего состава (г/дм $\left.{ }^{3}\right)$ : кальций хлористый 6-водный - 34,00; магний хлористый 6-водный - 17,00; натрий хлористый - 163,00 ; кальций сернокислый 2-водный - 0,14. Испытуемый ингибитор коррозии вводили в раствор в количестве 0,3 моль $/ \mathrm{m}^{3}$. Изучали зависимость потери массы $(\Delta m)$ от времени выдержки $(\tau)$ стальных образцов в коррозионной среде (рис. 4) и вычисляли защитную способность ингибитора по формуле

$$
Z=\frac{\Delta m_{\text {ни }}-\Delta m_{\text {и }}}{\Delta m_{\text {ни }}} \cdot 100 \%,
$$

где $\Delta m_{\text {ни, }} \Delta m_{\text {и }}$ - потеря массы образца в неингибированной и ингибированной системе соответственно, г. 


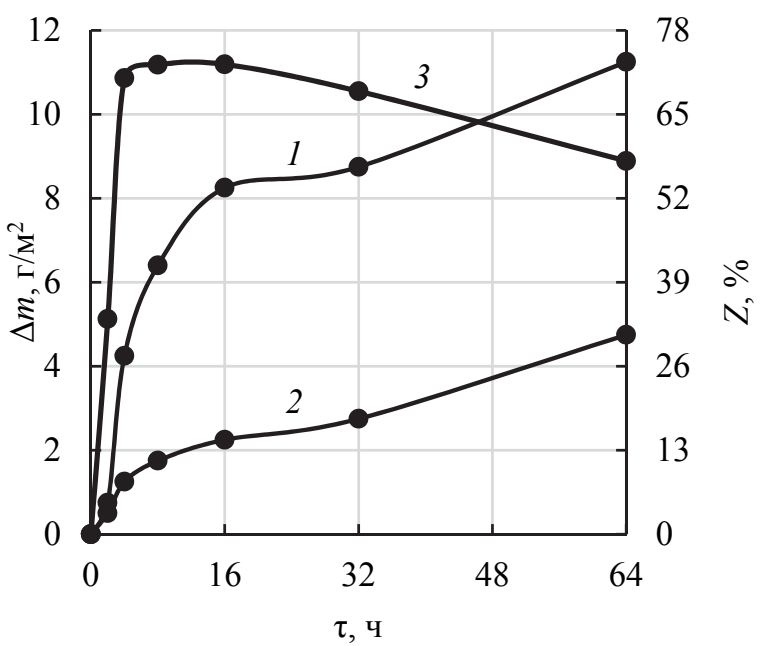

Рис. 4. Кривые потери массы стальным образцом без ингибитора (1) и в присутствии ингибитора коррозии (2), а также зависимость защитной способности ингибитора от времени (3)

Согласно рис. 4, коррозионный процесс протекал через ряд последовательных стадий: 1) индукционный период ( $\leq 2$ ч); 2) резкий рост скорости коррозии (2-16 ч); 3) пассивация поверхности образца ( 16-32 ч); 4) период равномерной коррозии (>32 ч). Примечательно, что указанные стадии наблюдались как в неингибированной, так и ингибированной системе, однако в присутствии ингибитора коррозии потеря массы стальным образцом значительно уменьшалась.

В первые 16 ч коррозионного процесса защитная способность испытуемых 2-алкил-1-(2-аминоэтил)2-имидазолинов достигала наибольшего значения (73\%) и в дальнейшем плавно снижалась, возможно, по причине постепенного гидролиза молекул ПАВ и десорбции с защищаемой поверхности.
В целом смесь 1-(2-аминоэтил)-2-пентадецил-2-имидазолина и 1-(2-аминоэтил)-2-гептадецил-2-имидазолина обеспечивает достаточно высокую степень коррозионной защиты углеродистой стали, хотя и несколько уступает по эффективности 2-алкил-2-имидазолинам, полученным из этилендиамина [9], по-видимому, из-за меньшей поверхностной активности.

Заключение. Синтез 2-алкил-1-(2-аминоэтил)-2-имидазолинов из карбоновых кислот и диэтилентриамина, протекающий через стадии нейтрализации, ацилирования и циклизации, сопровождается значительным побочным образованием диацильных производных диэтилентриамина, подавить которое простым избытком аминного реагента не удается. Получить 2-алкил-1-(2-аминоэтил)-2-имидазолины высокой чистоты из смеси высших жирных кислот в одном реакторе за одну технологическую операцию, без дополнительных операций выделения и очистки можно, выбрав начальную температуру синтеза, обеспечивающую протекание реакции ацилирования минуя предварительную стадию образования солей аммония, и применив способ смешения реагентов, препятствующий образованию димеров кислоты в реакционной смеси.

1-(2-Аминоэтил)-2-пентадецил-2-имидазолин и 1-(2-аминоэтил)-2-гептадецил-2-имидазолин, полученные в виде смеси непосредственно при синтезе из стеарина, в уксуснокислой форме хорошо растворимы в воде, при этом проявляют свойства коллоидных катионных ПАВ и имеют достаточно высокую поверхностную активность. Полученное смесевое ПАВ может применяться в качестве ингибитора коррозии углеродистых сталей, а также как компонент моющих средств и замасливателей текстильных нитей.

\section{Список литературы}

1. Mehedi Sh., Tepe J. J. Recent advances in the synthesis of imidazolines (2009-2020) // Advanced Synthesis \& Catalysis. 2020. Vol. 362, issue 20. P. 4189-4225. DOI: 10.1002/adsc.202000709.

2. Han Liu, Da-Ming Du. Recent advances in the synthesis of 2-imidazolines and their applications in homogeneous catalysis // Advanced Synthesis \& Catalysis. 2009. Vol. 351, issue 4. P. 489-519. DOI: 10.1002/adsc. 200800797.

3. Bajpai D., Tyagi V. K. Fatty imidazolines: chemistry, synthesis, properties and their industrial applications // Journal of Oleo Science. 2006. Vol. 55, issue 7. P. 319-329. DOI: 10.5650/jos.55.319.

4. Jawich M. W. S., Oweimreen G. A., Ali Sh. A. Heptadecyl-tailed mono- and bis-imidazolines: A study of the newly synthesized compounds on the inhibition of mild steel corrosion in a carbon dioxide-saturated saline medium // Corrosion Science. 2012. Vol. 65. P. 104-112. DOI: 10.1016/j.corsci.2012.08.001.

5. Разработка технологии получения имидазолинов - ингибиторов коррозии / А. Д. Бадикова [и др.] // Нефтехимия. 2016. Т. 56, № 4. C. 419-424. DOI: 10.7868/S0028242116040031.

6. Experimental and QSAR study on the surface activities of alkyl imidazoline surfactants / X. Kong [et. al] // Journal of molecular structure. 2018. Vol. 1156. P. 164-171. DOI: 10.1016/j.molstruc.2017.11.102.

7. Абрамзон А. А., Зайченко Л. П., Файнгольд С. И. Поверхностно-активные вещества. Синтез, анализ, свойства, применение. Л.: Химия, 1988. 200 с.

8. Синтез и коллоидно-химические свойства продуктов конденсации алифатических кислот с этиленаминами. 2-Алкил-2-имидазолины / В. И. Лысенко [и др.] // Коллоидный журнал. 1976. T. XXXVIII, № 5. C. 914-918. 
9. Юсевич А. И., Осипенок Е. М., Трусов К. И. Синтез и свойства 2-замещенных имидазолинов на основе метиловых эфиров жирных кислот // Труды БГТУ. Сер. 2, Химические технологии, биотехнологии, геоэкология. 2019. № 2 (223). С. 120-126.

\section{References}

1. Mehedi Sh., Tepe J. J. Recent advances in the synthesis of imidazolines (2009-2020). Advanced Synthesis \& Catalysis, 2020, vol. 362, issue 20, pp. 4189-4225. DOI: 10.1002/adsc.202000709.

2. Han Liu, Da-Ming Du. Recent advances in the synthesis of 2-imidazolines and their applications in homogeneous catalysis. Advanced Synthesis \& Catalysis, 2009, vol. 351, issue 4, pp. 489-519. DOI: 10.1002/adsc.200800797.

3. Bajpai D., Tyagi V. K. Fatty imidazolines: chemistry, synthesis, properties and their industrial applications. Journal of Oleo Science, 2006, vol. 55, issue 7, pp. 319-329. DOI: 10.5650/jos.55.319.

4. Jawich M. W. S., Oweimreen G. A., Ali Sh. A. Heptadecyl-tailed mono- and bis-imidazolines: A study of the newly synthesized compounds on the inhibition of mild steel corrosion in a carbon dioxide-saturated saline medium. Corrosion Science, 2012, vol. 65, pp. 104-112. DOI: 10.1016/j.corsci.2012.08.001.

5. Badikova A. D., Galyautdinova A. A., Kashaeva S. R., Kudasheva F. Kh., Zadkin M. A., Mortikov E. S. Development of technology for imidazolines - corrosion inhibitors. Petroleum Chemistry, 2016, vol. 56, no. 4, pp. 419-424. DOI: 10.7868/S0028242116040031.

6. Kong X., Qian Ch., Fan W., Liang Z. Experimental and QSAR study on the surface activities of alkyl imidazoline surfactants. Journal of molecular structure, 2018, vol. 1156, pp. 164-171. DOI: 10.1016/j.molstruc.2017.11.102.

7. Abramzon A. A., Zaychenko L. P., Fayngold S. I. Poverkhnostno-aktivnyye veshchestva. Sintez, analiz, svoystva, primeneniye [Surfactants. Synthesis, analysis, properties, application]. Leningrad, Khimiya Publ., 1988. 200 p.

8. Lysenko V. I., Verezhnikov V. N., Krut' V. V., Chistyakov B. E. Synthesis and colloidal-chemical properties of the condensation products of aliphatic acids with ethyleneamines. 2-Alkyl-2-imidazolines. Kolloidnyy zhurnal [Colloid Journal], 1976, vol. XXXVIII, no. 5, pp. 914-918 (In Russian).

9. Usevich A. I., Asipionak K. M., Trusau K. I. Synthesis and properties of 2-substituted imidazolines based on fatty acid methyl esters. Trudy BGTU [Proceedings of BSTU], issue 2, Chemical Engineering, Biotechnologies, Geoecology, 2019, no. 2 (223), pp. 120-126 (In Russian).

\section{Информация об авторах}

Юсевич Андрей Иосифович - кандидат химических наук, доцент, заведующий кафедрой нефтегазопереработки и нефтехимии. Белорусский государственный технологический университет (220006, г. Минск, ул. Свердлова, 13a, Республика Беларусь). E-mail: yusevich@belstu.by, usevich@mail.ru

Цалко Виктория Валерьевна - студент. Белорусский государственный технологический университет (220006, г. Минск, ул. Свердлова, 13a, Республика Беларусь). Е-mail: victoria.tsalko8@gmail.com

Осипенок Екатерина Михайловна - преподаватель-стажер кафедры нефтегазопереработки и нефтехимии. Белорусский государственный технологический университет (220006, г. Минск, ул. Свердлова, 13a, Республика Беларусь). E-mail: ekaterinaosipenok@gmail.com

Куземкин Дмитрий Владимирович - кандидат технических наук, доцент кафедры нефтегазопереработки и нефтехимии. Белорусский государственный технологический университет (220006, г. Минск, ул. Свердлова, 13a, Республика Беларусь). E-mail: kuziomkin@mail.ru

\section{Information about the authors}

Usevich Andrew Iosifovich - PhD (Chemistry), Associate Professor, Head of the Department of Oil and Gas Processing and Petroleum Chemistry. Belarusian State Technological University (13a, Sverdlova str., 220006, Minsk, Republic of Belarus). E-mail: yusevich@belstu.by, usevich@mail.ru

Tsalko Viktoria Valerievna - student. Belarusian State Technological University (13a, Sverdlova str., 220006, Minsk, Republic of Belarus). E-mail: victoria.tsalko8@gmail.com

Asipionak Katsiaryna Mikhaylauna - Trainee teacher, the Department of Oil and Gas Processing and Petroleum Chemistry. Belarusian State Technological University (13a, Sverdlova str., 220006, Minsk, Republic of Belarus). E-mail: ekaterinaosipenok@gmail.com

Kuzemkin Dmitriy Vladimirovich - PhD (Engineering), Assistant Professor, the Department of Oil and Gas Processing and Petroleum Chemistry. Belarusian State Technological University (13a, Sverdlova str., 220006, Minsk, Republic of Belarus). E-mail: kuziomkin@mail.ru 